\title{
PENGARUH NATRIUM METABISULFIT DAN PROSES MEKANIK TERHADAP KUALITAS TALAS BLOK
}

\section{Effect of Sodium Metabisulphite and Mechanical Process on Block Taro Quality}

\author{
Wilsa Hermianti* dan Firdausni \\ Baristand Industri Padang ${ }^{1)}$ \\ JI. Raya LIK No. 23 Ulu Gadut \\ *e-mail: wilsadjaswir@gmail.com
}

Diterima: 14 Februari 2013, Disetujui: 30 April 2013

\begin{abstract}
ABSTRAK
Talas kimpul (Xanthosoma sagittifolium) mengandung karbohidrat berupa pati yang cukup tinggi sehingga dapat berfungsi sebagai bahan pangan karbohidrat non beras. Talas menimbulkan rasa gatal dan berlendir yang disebabkan oleh kandungan kalsium oksalat. Umur simpan talas hanya 1-2 minggu. Oleh karena itu tanpa proses pengolahan akan menyulitkan dalam penyimpanan dan transportasi. Talas blok belum diproduksi, dan belum ada literatur yang menyatakan teknologi proses dan pengolahannya. Penelitian ini dilakukan untuk mengurangi rasa gatal dan lendir, memudahkan dalam transportasi dan distribusi, serta untuk memperpanjang umur simpan dengan perlakuan perendaman dalam larutan garam $1 \%$, larutan natrium metabisulfit $0,1 \%$ dan kombinasi perendaman larutan garam $1 \%$ dengan penambahan natrium metabisulfit $0,1 \%$, kemudian membandingkan proses pembuatan talas blok secara manual dan secara mekanik. Analisis yang dilakukan terhadap kadar air, kadar abu, kadar pati, kalsium oksalat, protein dan sulfit tersisa serta uji organoleptik oleh panelis. Hasil penelitian menunjukkan bahwa perendaman dalam larutan Natrium metabisulfit selama 20 jam memberikan hasil yang optimum dengan kadar Kalsium oksalat 0,13\%, sulfit tersisa $1,39 \mathrm{mg} / \mathrm{kg}$, kadar abu $1,12 \%$, kadar pati $73,37 \%$, protein $3,4 \%$, dan hasil uji organoleptik nilai warna dan aroma talas blok disukai panelis serta masa simpan 8 bulan masih dalam keadaan baik. Pembuatan talas blok dengan sistim press cetak mekanik menghasilkan kandungan Kalsium oksalat $0,065 \%$, rendemen $21,38 \%$, sulfit tersisa $1,39 \mathrm{mg} / \mathrm{kg}$, mampu menghemat waktu pengeringan selama 7 jam dengan oven suhu $40^{\circ} \mathrm{C}$.
\end{abstract}

\section{Kata Kunci : Natrium metabisulfit, proses mekanik, talas blok}

\section{ABSTRACT}

Kimpul Taro (Xanthosoma sagittifolium) contains high starch as non-rice carbohydrate source. Taro have itching and mucu caused by Calcium oxalate content. Its shelf life only 1- 2 weeks therefore, without treatment processing it would be difficult in transportation. There is absence literature on taro block production. The research was done to decrease itching taste and mucus, simply in transportation and distribution, so to lenghten of shelf life with processing treatments are soaking in $1 \%$ sodium chloride, soaking in $0,1 \%$ sodium metabisulphite, and its combination, and comparising processing of block taro between manual and mechanical press. The analysis was done on several parameters that influence to quality and shelf life of taro block such as water content, level of ash, starch, calcium oxalate, protein and sulphite residue, and organoleptic test by panelist. The result of research showed that soaking in solution of $0.1 \%$ sodium metabisulphite for 20 hours gave optimum result with content of calcium oxalate was $0.13 \%$, residue of suphite was $1.39 \mathrm{mg} / \mathrm{kg}$, level of ash $1.12 \%, 73,37 \%$ starch, protein $3.4 \%$, and organoleptic test of colour and smell value of block taro were preferred by panelists and storage time for 8 months still in good condition. The making of taro block with press mechanic systems had calcium oxalate content $0.065 \%$, yield $21.38 \%$, residue of sulphite $1.39 \mathrm{mg} / \mathrm{kg}$, was able to decrease drying times for 7 hours with drying oven at $40^{\circ} \mathrm{C}$.

\section{Keywords : Sodium metabisulphite, mechanical process, block taro}




\section{PENDAHULUAN}

Kemampuan produksi pangan dalam negeri dari tahun ke tahun semakin terbatas. Agar kecukupan pangan nasional bisa terpenuhi, maka upaya yang dilakukan adalah meningkatkan produktivitas budidaya pangan dengan pemanfaatan teknologi dan upaya diversifikasi pangan. Kebutuhan karbohidrat yang terus meningkat dimana penyediaan karbohidrat dari serealia saja tidak mencukupi, sehingga peranan tanaman penghasil karbohidrat dari umbi-umbian khususnya talas semakin penting. Pengolahan bahan pangan merupakan upaya untuk meningkatkan pendayagunaan potensi sumber daya alam terutama sumber daya nabati sebagai sumber pangan. Potensi talas sebagai sumber pangan lokal diharapkan dapat menjadi sumber penyediaan bahan pangan karbohidrat non beras, diversifikasi konsumsi pangan lokal, mensubstitusi penggunaan tepung terigu. Di beberapa daerah/propinsi tanaman talas telah banyak dimanfaatkan sebagai bahan pangan.

Talas sudah dikenal masyarakat karena umbinya yang lezat dan mudah diolah bahkan di kepulauan Mentawai dan Papua, talas dimakan sebagai makanan pokok bagi penduduk asli. Daerah Sumatera Barat juga cukup potensi dengan talas terutama di kabupaten Mentawai, Pesisir Selatan, dan Padang Pariaman, namun belum terdata dengan jelas (Jusuf dan Marzempi, 1993).

Talas banyak jenisnya, diantaranya yang banyak ditemui di Sumatera Barat dan di pasar-pasar tradisional adalah talas bondang atau disebut juga talas belitung, kimpul, busil, bote (Xanthosoma sagittifolium). Pemanfaatan umbi talas sebagai bahan pangan masih terbatas, umumnya sebagai makanan tambahan seperti direbus, dikukus, digoreng, dibuat getuk, kolak atau keripik. Umbi talas juga dapat diolah menjadi tepung talas yang lebih luas penggunaannya yaitu dapat digunakan sebagai bahan untuk sop, biskuit, roti, minuman beralkohol, makanan bayi, puding, pasta, permen dan makanan ringan lainnya. Talas blok belum diproduksi dan sampai saat ini belum ada teknologi proses pengolahan talas blok (Hermianti dkk, 2010)

Umumnya talas menimbulkan rasa gatal dan dapat menyebabkan pembengkakan di lidah, mulut dan kerongkongan saat dimakan dalam keadaan tanpa pengolahan. Hal tersebut disebabkan oleh kandungan Kalsium oksalat yang berpenetrasi pada kulit yang halus (Bradbury and Nixon, 1998 ; Maulina, Lestari, dan Retnowati, 2012). Talas juga berlendir sehingga sulit dalam pengolahan. Talas dalam bentuk segar dan tanpa pengolahan menyulitkan dalam transportasi dan umur simpannya hanya 1 2 minggu.

Penelitian pengolahan talas menjadi talas blok ini bertujuan untuk memaksimalkan pemanfaatan talas sebagai sumber pangan, dan ketersediaannya dalam bentuk yang siap digunakan, mudah dalam pendistribusian dan transportasi, untuk mengurangi rasa gatal serta untuk meningkatkan masa simpan. Penggunaan Natrium metabisulfit $\left(\mathrm{Na}_{2} \mathrm{~S}_{2} \mathrm{O}_{5}\right)$ dapat menekan degradasi warna dan memperpanjang masa simpan (Latapi and Barett, 2006).

\section{METODOLOGI PENELITIAN}

\section{Bahan}

Bahan yang digunakan adalah umbi talas kimpul (Xanthosoma sagittifolium), natrium metabisulfit, garam, bahan kemasan dan bahan kimia untuk pengujian $(\mathrm{HCl}$, $\mathrm{NAOH}, \mathrm{KI}$, glukosa, aquades, methylen blue, Fehling A, Fehling $B$, kalium, sodium tartrat, $\mathrm{H}_{2} \mathrm{SO}_{4}$, indikator phenolphtalein, asam boraks, $\mathrm{KMNO}_{4}$, dan lain-lain).

\section{Alat}

Alat-alat yang digunakan untuk analisis adalah neraca, oven, destilator kjedhal, furnace.

Rancangan yang digunakan dalam 
penelitian ini mencakup pembuatan talas blok secara press manual dan secara press mekanik dengan rancangan sebagai berikut.

\section{Pelaksanaan Penelitian}

Pembuatan Talas Blok Secara Press Manual

Pembuatan talas blok menggunakan alat press dan cetak manual dengan variasi perlakuan pendahuluan untuk mengurangi kalsium oksalat pada talas sebagai berikut:

\section{A : Perendaman dalam larutan garam $1 \%$ \\ B : Perendaman dalam larutan Natrium metabisulfit $0,1 \%$ \\ C : Perendaman dalam larutan garam 1\% dan Natrium metabisulfit $0,1 \%$ (dicampur)}

Pembuatan Talas Blok Secara Press Mekanik

Pembuatan talas blok menggunakan alat press dan cetak mekanik tidak dilakukan lagi variasi perlakuan pendahuluan (diambil perlakuan yang terbaik). Hasil press dan cetak sistim mekanik dibandingkan dengan hasil press dan cetak sistim manual. Diagram alir pembuatan talas blok adalah seperti pada Gambar 1.

\section{Analisis}

Analisis yang dilakukan meliputi: analisis kimia bahan baku talas kimpul segar (kadar air, pati dan kalsium oksalat) dan produk talas blok (kadar air, abu, pati, protein, kalsium oksalat dan sulfit tersisa. Uji organoleptik produk talas blok oleh panelis (warna dan aroma) dengan skala numerik 5 = sangat suka, 4 = suka, $3=$ cukup suka, 2 = kurang suka, 1 = tidak suka. Pengamatan masa simpan talas blok (secara visual dan kadar air setiap bulan selama 3 bulan penyimpanan). Hasil penggunaan alat press manual dan mekanik dianalisis kadar rendemen umbi talas, rendemen talas blok, kadar sulfit tersisa, kadar kalsium oksalat, kadar air dan pengamatan lama pengeringan.

\section{Talas}

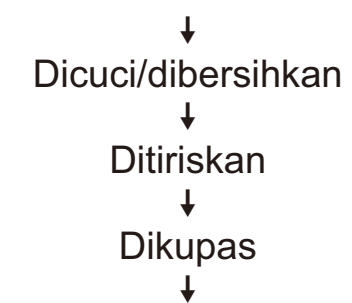

Diiris ketebalan $\pm 1 \mathrm{~mm}$

$\downarrow$

Direndam dalam larutan garam $1 \%$ dan atau Natrium metabisulfit $0,1 \% \pm 20$ jam

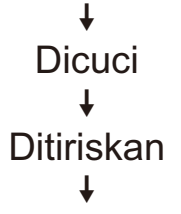

Dihaluskan dengan blender sampai halus $\downarrow$

Dipress

$\downarrow$

Dicetak

$\downarrow$

Dikeringkan dengan oven suhu $40^{\circ} \mathrm{C}$ sampai kering $\downarrow$

Talas Blok

Gambar 1. Diagram Alir Pembuatan Talas Blok

\section{HASILDAN PEMBAHASAN}

\section{Hasil Analisis Bahan Baku}

Analisis bahan baku pada talas kimpul meliputi kadar air, kadar pati dan kadar Kalsium oksalat seperti terlihat pada Tabel 1.

Tabel 1. Hasil analisis kimia talas kimpul.

\begin{tabular}{|l|c|}
\hline Parameter yang diamati & Jumlah \\
\hline Kadar air (\%) & 76,09 \\
\hline Kadar pati (\%) & 15,88 \\
\hline Kadar Kalsium Oksalat (\%) & 0,18 \\
\hline
\end{tabular}

Pada Tabel 1 dapat terlihat kadar air talas kimpul $76,09 \%$, kadar pati $15,88 \%$ dan kadar kalsium oksalat $0,18 \%$. Talas sebagaimana hasil pertanian pada umumnya mempunyai kadar air yang tinggi. Menurut Herman (1991) kadar air sangat berpengaruh terhadap mutu bahan pangan. Hal ini merupakan salah satu sebab dilakukan pengurangan atau pengeluaran air dari bahan pangan di dalam pengolahan 
misalnya dengan cara penguapan atau pengeringan. Ditambahkan oleh Sediaoetama (1996) bahwa kondisi kadar air yang tinggi tersebut akan menguntungkan pertumbuhan mikroba yang akan menyebabkan kerusakan bahan pangan.

Dalam rangka meningkatkan umur simpan dan kegunaan talas dilakukan pengolahannya menjadi talas blok yang sesuai dengan tujuan pengembangan teknologi pengolahan yakni agar bahan pangan tahan disimpan dalam jangka panjang tanpa mengalami kerusakan yang terlalu banyak, dapat dipasarkan dalam kondisi baik (lebih padat dan lebih mudah dikemas), akan lebih memudahkan dalam pengangkutan (transportasi dan distribusi) sekaligus penganekaragaman bahan pangan.

Manfaat utama dari umbi talas menurut Prihatman (2000) adalah sebagai bahan pangan sumber karbohidrat baik sebagai makanan utama maupun makanan pokok karena talas mengandung karbohidrat berupa pati yang cukup tinggi. Menurut Slamet dan Tarkotjo (1980) umbi talas mengandung pati yang mudah dicerna kirakira sebanyak $18,2 \%$. Karbohidrat dipahami sebagai nutrisi yang banyak dikandung beras namun sebenarnya karbohidrat juga dapat ditemui dalam bahan pangan lain seperti ubi kayu, ubi jalar, talas dan lain sebagainya.

Kebutuhan karbohidrat dari tahun ke tahun terus meningkat sementara kemampuan produksi pangan semakin terbatas dan penyediaan karbohidrat dari serelia saja tidak mencukupi sehingga peranan tanaman penghasil karbohidrat dari umbi-umbian khususnya talas menjadi semakin penting. Tanaman talas menjadi sangat penting artinya di dalam kaitannya terhadap upaya penyediaan bahan pangan karbohidrat non beras, diversifikasi konsumsi pangan lokal, substitusi terigu, serta pengembangan industri pengolahan.

Setiap bahan pangan mempunyai karakteristik tersendiri, begitu juga dengan talas. Talas mengandung kalsium oksalat yang bisa menyebabkan rasa gatal-gatal dan iritasi pada kulit dan tenggorokan pada manusia bila mengkonsumsinya namun kalsium oksalat ini sangat bermanfaat untuk proses metabolisme dan pertahanan internal bagi talas (Maulina dkk, 2012). Berdasarkan hasil analisis pada talas kimpul segar terdapat kandungan Kalsium oksalat $0,18 \%$. Kandungan Kalsium oksalat ini dapat dikurangi dengan melakukan pengolahan.

\section{Talas Blok}

Pembuatan talas blok dengan perlakuan pendahuluan pengurangan kadar kalsium oksalat dari talas kimpul diperoleh hasil seperti pada Tabel 2.

Tabel 2. Hasil Analisis Kimia Talas Blok

\begin{tabular}{|l|c|c|c|}
\hline \multirow{2}{*}{ Parameter } & \multicolumn{3}{|c|}{ Perlakuan } \\
\cline { 2 - 4 } & $\mathrm{A}$ & $\mathrm{B}$ & $\mathrm{C}$ \\
\hline Kadar air (\%) & 15,90 & 12,40 & 15,60 \\
\hline Kadar abu (\%) & 2,11 & 1,12 & 1,68 \\
\hline Kadar pati (\%) & 68,84 & 73,37 & 73,21 \\
\hline Protein (\%) & 2,55 & 3,40 & 1,07 \\
\hline $\begin{array}{l}\text { Kalsium } \\
\text { Oklasalat (\%) }\end{array}$ & 0,086 & 0,130 & 0,177 \\
\hline $\begin{array}{l}\text { Sulfit tersisa } \\
\text { (mg/kg) }\end{array}$ & TTD & 1,39 & 2,78 \\
\hline
\end{tabular}

Keterangan :

TTD = Tidak Terdeteksi

$\mathrm{A}=$ Perendaman dalam larutan garam $1 \%$

$\mathrm{B}=$ Perendaman dalam larutan Natrium metabisulfit $0,1 \%$

C = Perendaman dalam larutan garam $1 \%$ dan Natrium metabisulfit $0,1 \%$

Dari data pada Tabel 2 terlihat bahwa perlakuan pendahuluan pengurangan kandungan

kalsium oksalat dari talas kimpul dengan perendaman dalam larutan garam $1 \%$ (A) selama 20 jam, mampu mengurangi kadar Kalsium oksalat dari talas kimpul lebih banyak yakni $0,094 \%$ dari $0,18 \%$ menjadi $0,086 \%$ dibanding dengan Natrium metabisufit $0,1 \%(B)$ dan gabungan keduanya (C) yang hanya mampu mengurangi kandungan Kalsium oksalat berturut-turut $0,05 \%$ (dari $0,18 \%$ menjadi $0,13 \%$ ) dan $0,003 \%$ (dari $0,18 \%$ menjadi $0,177 \%$ ). Hal ini sesuai pendapat Slamet dan Tarkotjo (1980) bahwa untuk mendapatkan kadar kalsium oksalat yang rendah pada talas dapat dilakukan dengan merendam talas dalam larutan garam $(\mathrm{NaCl}) 1 \%$ selama 20 
menit namun berdasarkan hasil pra penelitian yang telah dilakukan bahwa perendaman dalam larutan garam 1\% selama 20 menit belum memberikan hasil pengurangan lendir dan kalsium oksalat yang maksimal dari talas sehingga diperpanjang dan yang memberikan hasil yang optimal yakni dengan waktu perendaman selama 20 jam. Menurut Sefa, Agyir dan Sackey (2004) kadar Kalsium oksalat yang layak untuk konsumsi $71 \mathrm{mg} / \mathrm{kg}$.

Penurunan kadar oksalat terjadi karena reaksi antara Natrium klorida $(\mathrm{NaCl})$ dan Kalsium oksalat $\left(\mathrm{CaC}_{2} \mathrm{O}_{4}\right)$. Garam $(\mathrm{NaCl})$ dilarutkan dalam air terurai menjadi ion-ion $\mathrm{Na}^{+}$dan $\mathrm{Cl}^{-}$. Ion-ion tersebut bersifat seperti magnet. Ion $\mathrm{Na}^{+}$menarik ion-ion yang bermuatan negatif dan ion $\mathrm{Cl}^{-}$menarik ionion yang bermuatan positif. Sedangkan Kalsium oksalat $\left(\mathrm{CaC}_{2} \mathrm{O}_{4}\right)$ dalam air terurai menjadi ion-ion $\mathrm{Ca}^{2+}$ dan $\mathrm{C}_{2} \mathrm{O}_{4}{ }^{2-}$. $\mathrm{Na}+$ mengikat ion $\mathrm{C}_{2} \mathrm{O}_{4}{ }^{2-}$ membentuk Natrium oksalat $\left(\mathrm{Na}_{2} \mathrm{C}_{2} \mathrm{O}_{4}\right)$. Ion $\mathrm{Cl}$ mengikat $\mathrm{Ca}^{2+}$ membentuk endapan putih Kalsium diklorida $\left(\mathrm{CaCl}_{2}\right)$ yang mudah larut dalam air (Slamet dan Tarkotjo, 1980).

$$
\mathrm{CaC}_{2} \mathrm{O}_{4}+2 \mathrm{NaCl} \rightarrow \mathrm{Na}_{2} \mathrm{C}_{2} \mathrm{O}_{4}+\mathrm{CaCl}_{2} \ldots \ldots \ldots \text { (1) }
$$

Perendaman dalam larutan gabungan Natrium metabisulfit dan garam memberikan pengurangan yang lebih kecil. Hal ini dapat terjadi karena $\mathrm{NaCl}$ dan $\mathrm{Na}_{2} \mathrm{~S}_{2} \mathrm{O}_{5}$ dalam air saling berikatan sehingga fungsinya dalam mengurangi kalsium oksalat tidak maksimal.

Penggunaan larutan garam dalam perendaman talas (A) memberikan hasil kandungan garam pada talas blok $0,35 \%$ sedangkan dari penggunaan Natrium metabisulfit (B) diperoleh talas blok dengan kadar sulfit tersisa $1,39 \mathrm{mg} / \mathrm{kg}$ dan $C$ dengan sulfit tersisa $2,78 \mathrm{mg} / \mathrm{kg}$. Menurut Winarno (1993) maksimum penggunaan Natrium metabisulfit pada makanan $300 \mathrm{mg} / \mathrm{kg}$. Jadi dapat dinyatakan bahwa garam yang tersisa pada talas blok relatif kecil begitu juga dengan natrium metabisulfit yang tersisa pada talas blok sangat kecil sekali. Hal ini sesuai dengan pendapat Margono dkk (1993) bahwa Natrium metabisulfit yang berlebih akan hilang sewaktu pengeringan dan pemanasan.

Talas blok yang dihasilkan dari penelitian ini mempunyai kadar air rata-rata
$14,63 \%$, dan kadar abu $1,64 \%$, kadar pati $71,81 \%$ dan protein $2,34 \%$. Menurut Widiyawati (2007) Natrium metabisulfit dapat menghambat penurunan kadar protein. Bila dibandingkan dengan tepung terigu, memang tepung yang dihasilkan dari talas blok ini masih di bawah persyaratan SNI 01-3751-1995 tepung terigu, dimana kadar air maksimal 14\%, kadar abu maks. $0,6 \%$, kadar protein maks. $12 \%$.

Hasil uji organoleptik talas blok dengan perlakuan pendahuluan pengurangan kadar Kalsium oksalat dari talas kimpul dapat dilihat pada Tabel 3 .

Tabel 3. Pengaruh perlakuan pengurangan kadar kalsium oksalat terhadap nilai organoleptik warna dan aroma talas blok

\begin{tabular}{|c|c|c|}
\hline \multirow{2}{*}{ Perlakuan } & \multicolumn{2}{|c|}{ Nilai Organoleptik } \\
\cline { 2 - 3 } & Warna & Aroma \\
\hline A & $1,68 \mathrm{a}$ & $2,40 \mathrm{a}$ \\
\hline B & $3,52 \mathrm{~b}$ & $3,40 \mathrm{~b}$ \\
\hline Talas blok & yano, dópleroleh drosplerla-
\end{tabular}

kuan pengurangan kadar Kalsium oksalat dengan menggunakan garam, Natrium metabisulfit dan gabungan keduanya setelah diuji secara organoleptik oleh panelis terhadap warna dan aromanya menunjukkan hasil bahwa perlakuan perendaman dengan Natrium metabisulfit $0,1 \%$ memberikan nilai warna dan aroma yang lebih disukai panelis yakni warnanya lebih putih dibanding perlakuan perendaman dalam larutan garam $1 \%$ atau gabungan keduanya. Hal ini sesuai dengan fungsi Natrium metabisulfit menurut Margono, dkk (1993) untuk mencegah proses pencoklatan dan mempertahankan warna agar tetap menarik. Menurut Mathew and Parpia (1971) dan Flick et al (1977) pencoklatan pada bahan pangan disebabkan oleh reaksi mekanis selama panen, pasca panen, penyimpanan dan pengolahan, dan merupakan penyebab utama dari penurunan mutu.

Talas blok dapat dikemas dalam kantong plastik yang di seal atau dalam kotak plastik yang ditutup dengan segel. Selama penyimpanan talas blok dilakukan pengamatan secara visual setiap bulan dan dianalisis kadar air sekali sebulan selama 3 bulan penyimpanan. Hasil pengamatan daya 
simpan secara visual terhadap warna dan aroma talas blok dari ke tiga perlakuan perendaman tersebut sampai 8 bulan penyimpanan masih baik (normal). Hal ini didukung dengan data kadar air selama 3 bulan penyimpanan (Tabel 4) menunjukkan hasil yang relatif stabil atau cenderung sedikit berkurang.

Tabel4. Kadar Air Talas Blok Selama 3 Bulan Penyimpanan

\begin{tabular}{|c|c|c|c|c|}
\hline \multirow{2}{*}{ Perlakuan } & \multicolumn{4}{|c|}{ Kadar air (\%) Bulan ke } \\
\hline & 0 & 1 & 2 & 3 \\
\hline$A$ & 15,90 & 14,59 & 14,11 & 14,53 \\
\hline$B$ & 12,40 & 12,13 & 12,59 & 12,31 \\
\hline Ka & 156 & & & \\
\hline
\end{tabular}

mutu bahan pangan dan pada umumnya keawetan bahan pangan mempunyai hubungan yang erat dengan kadar air yang dikandungnya. Bahan pangan atau makanan dengan kadar air yang lebih rendah umumnya mempunyai ketahanan yang lebih lama (Herman, 1991).

Secara umum setelah 3 bulan penyimpanan kadar air talas blok menurun dibanding kadar air awal talas blok tetapi pada perlakuan perendaman dalam larutan Natrium metabisulfit $0,1 \%$ pada bulan ke 2 terjadi kenaikan kadar airnya dan perlakuan perendaman dalam larutan garam $1 \%$ pada bulan ke 3 kadar airnya juga meningkat dibanding pada bulan kedua namun pada perlakuan perendaman dalam larutan garam $1 \%$ dan Natrium metabisulfit $0,1 \%$ semakin lama penyimpanan kadar airnya semakin menurun. Hal ini dapat terjadi karena sifat higroskopis produk namun bisa juga karena kondisi kadar air produk yang masih kurang homogen selama pengeringan.

\section{Pengembangan proses pembuatan talas Blok secara mekanik.}

Pengembangan teknologi peralatan yang dilakukan yakni setelah talas dihaluskan, diperas terlebih dahulu untuk mengurangi kadar airnya dengan menggunakan spinner kapasitas $3 \mathrm{~kg}$ dengan daya 320 watt, kecepatan putar 1.350 rpm selama 15 menit. Setelah dikurangi kadar airnya dengan alat spinner kemudian dimasukkan ke dalam alat press dengan sistim kompresor tekanan $5 \mathrm{~kg} / \mathrm{cm}^{2}$ selama 5 menit dan cetakan persegi ukuran $10 \times 10 \mathrm{~cm}$ (4 bh) sekali cetak dimana masing-masing cetakan berisi talas basah 300 gram dengan ketebalan $\pm 2 \mathrm{~cm}$ selanjutnya dikeringkan dengan oven daya 800 watt suhu $40^{\circ} \mathrm{C}$ selama 13 jam.

Hasil talas blok yang dibuat dengan pengembangan teknologi peralatan dibandingkan dengan peralatan press dan cetak manual serta seperti terlihat pada Tabel 5.

Tabel5. Perbandingan Hasil Penggunaan Alat Press dan Cetak Sistim Manual dengan Sistim Mekanik

\begin{tabular}{|l|c|c|}
\hline \multicolumn{1}{|c|}{ Hasil } & $\begin{array}{c}\text { Press dan } \\
\text { Cetak } \\
\text { Sistem Manual }\end{array}$ & $\begin{array}{c}\text { Press dan } \\
\text { Cetak } \\
\text { Sistem Mekanik }\end{array}$ \\
\hline $\begin{array}{l}\text { Rendemen } \\
\text { umbi talas dari } \\
\text { talas segar }\end{array}$ & $78,52 \%$ & $49,5 \%$ \\
\hline $\begin{array}{l}\text { Rendemen } \\
\text { talas blok dari } \\
\text { talas segar }\end{array}$ & $18,77 \%$ & $21,38 \%$ \\
\hline $\begin{array}{l}\text { Kadar Sulfit } \\
\text { Tersisa }\end{array}$ & $1,39 \mathrm{mg} / \mathrm{kg}$ & $1,39 \mathrm{mg} / \mathrm{kg}$ \\
\hline $\begin{array}{l}\text { Kadar Kalsium } \\
\text { Oksalat }\end{array}$ & $0,130 \%$ & $0,065 \%$ \\
\hline Kadar Air & $12,40 \%$ & $9,84 \%$ \\
\hline $\begin{array}{l}\text { Lama } \\
\text { pengmpiggadllihat data dari }\end{array}$ & $\begin{array}{c}13 \mathrm{jam} \\
5 \mathrm{bahwa}\end{array}$ \\
\hline
\end{tabular}

pengolahan dengan menggunakan mekanik (spinner) mampu mengurangi cairan dari bahan baku talas yang telah dihaluskan sebanyak $28,92 \%$ dibanding tanpa menggunakan spinner. Spinner ini prinsip kerjanya dengan sistim sentrifugal sehingga fase cair akan terlempar ke luar dan terpisah dari fase padat.

Kombinasi penggunaan spinner dan alat press cetak sistim mekanik dengan menggunakan kompresor mampu meningkatkan rendemen talas blok yang dihasilkan menjadi $21,38 \%$, mengurangi kadar air $2,56 \%$, kadar Kalsium oksalat separuhnya yakni $0,065 \mathrm{mg} / \mathrm{kg}$ dibanding secara manual serta mengurangi waktu pengeringan selama 7 jam. Hal ini disebabkan karena sudah 2 kali dikeluarkan cairan dari bahan bakunya yakni pertama dengan spinner $1.350 \mathrm{rpm}$ selama 15 menit dan yang kedua 
dengan press-cetak $5 \mathrm{~kg} / \mathrm{cm}^{2}$ selama 5 menit.

Alat press dan cetakan sistem manual terbuat dari plastik bentuk silinder diameter 9 $\mathrm{cm}$, tebal $1 \mathrm{~cm}$ dengan berat talas basah 100 gram. Alat press dan cetak sistem mekanik dikurangi kandungan air talas dengan spinner $1.350 \mathrm{rpm}$ selama 15 menit kemudian diperas sistim kompresor $5 \mathrm{~kg} / \mathrm{cm}^{2}$ selama 5 menit dan cetakan berbentuk persegi ukuran $10 \times 10 \mathrm{~cm}$ (4 bh), tebal $2 \mathrm{~cm}$ dengan berat talas basah yang telah dispinner untuk 1 buah cetakan sebanyak 300 gram.

\section{KESIMPULAN}

Dari hasil penelitian dapat disimpulkan sebagai berikut :

1. Kandungan karbohidrat berupa pati talas kimpul cukup tinggi (15,88\%) sehingga memungkinkan sebagai bahan pangan sumber karbohidrat pengganti beras dan subsitusi terigu .

2. Perlakuan pendahuluan dengan perendaman dalam larutan Natrium metabisulfit $0,1 \%$ selama 20 jam menghasilkan talas blok terbaik dengan kadar Kalsium oksalat $0,13 \%$, Sulfit tersisa $1,39 \mathrm{mg} / \mathrm{kg}$ dengan nilai warna 3,52 dan aroma 3,40 yang lebih disukai serta masa simpan lebih dari 8 bulan.

3. Pembuatan talas blok dengan menggunakan alat press cetak mekanik menghasilkan kandungan Kalsium oksalat lebih rendah separuhnya $(0,065 \%)$, rendemen talas blok lebih besar $(21,38 \%)$, serta mengurangi kadar air dan menghemat waktu pengeringan dengan oven suhu $40^{\circ} \mathrm{C}$ selama 7 jam.

\section{DAFTAR PUSTAKA}

Badan Standardisasi Nasional. 1995. SNI 01-3751-1995. Tepung terigu. Badan Standardisasi Nasional. Jakarta.

Bradbury J, Nixon R. 1998. The acridity of raphides from the edible aroids. Journal of the Science Food and Agricultural $76: 608-616$.

Flicks G.J. Ory, J.A. St. Angelo. 1977. Comparison of nutrient composition and of enzyme activity in purple, green and white eggplant. Journal of Agricultural and Food Chemistry, 25 : 117-120.

Herman, A.S. 1991. Pengetahuan bahan dan produk industry kecil pengolahan pangan. Direktorat Industri Pangan. Jakarta.

Hermianti, W., Firdausni, Kasim, M., Monandes Vetrio, dan Elya Rovina. 2010. Pengembangan teknologi dan analisis tekno ekonomi pembuatan talas blok (tepung, diversifikasi produk). Baristand Industri Padang.

Jusuf, M. dan Marzempi, MS. 1993. Pengolahan palawija dalam pengembangan agro industri. Balai Penelitian Tanaman Pangan Sukarami. Solok.

Latapi G, Barret D.M. 2006. Influence of pre drying treatment on quality and safety of sun-dried tomatoes, Part II. Effect of storage on nutritional and sensory quality of sun dried tomatoes pretreated with sulfur, sodium metabisulphite or salt. Journal Food Science 71 (1): 32-37.

Margono, T.,Suryati D., dan Hartinah S.. 1993. Teknologi pangan. PDII-LIPI. Jakarta.

Mathew A.G, H. Parpia. 1971. Food browning as a polyphenol reaction. Journal Advances in Food Research. 19.

Maulina, F.D.A, Lestari I.M., Retnowati D.S. 2012. Decrease of calcium oxalate content in taro tuber used $\mathrm{NaHCO} 3$ : as raw material of flour (in Indonesian). Journal Chemistry and Industry Technology. Vol.I. No.1.

Prihatman, K. 2000. Sistim informasi manajemen pembangunan di pedesaan. Bappenas. Jakarta.

Sediaoetama, Djaeni, A. 1996. Ilmu gizi. Dian Rakyat. Jakarta.

Sefa D., Agyir S., Sackey E.K. 2004. Chemical composition and the effect of 
processing on oxalate content of cocoyam, Xanthosoma sagittifolium and Colocasia esculenta cornels. Journal Food Chemistry.

Slamet, D.S. dan Ig. Tarkotjo. 1980. Majalah gizi dan makanan jilid 4. Pusat Penelitian dan Pengembangan Kesehatan. Depkes RI. Jakarta.

Widiyawati I.I. 2007. Effect of soaking time and metabisulphite on the flour quality from sweet potato (in Indonesian). Journal Agriculture Technology.

Winarno, F.G. 1993. Pangan, gizi, teknologi dan konsumen. PT. Gramedia Pustaka Utama. Jakarta. 